\title{
THE INFLUENCE OF POLITICAL AND SOCIAL TRUST ON PARTICIPATION OF PEOPLE IN POLITICS IN JAHROM CITY, IRAN
} Masoud Gerami ${ }^{1}$, Keramatollah Rasekh ${ }^{2 *}$, Majidreza Karimi ${ }^{3}$

${ }^{1}$ Ph.D. student of Political Sociology, Islamic Azad University, Jahrom Branch, Iran; ${ }^{2 *}$ Associate Professor of Sociology, Islamic Azad University, Jahrom Branch, Iran; ${ }^{3}$ Assistant Professor of Sociology, Islamic Azad University, Jahrom Branch, Iran.

Email: ${ }^{1}$ masoud7512@yahoo.com, ${ }^{2 *}$ krasekh@gmail.com, ${ }^{3}$ majidrezakarimi@ gmail.com

\author{
Article History: Received on $23^{\text {rd }}$ December 2019, Revised on $14^{\text {th }}$ April 2020, Published on $26^{\text {th }}$ May 2020
}

\begin{abstract}
Purpose of the study: The purpose of this study is to examine the implications of political and social trust for the political participation of people in Jahrom City, Iran. And also, this study tries to assess the effect of social media on people's trust, which can affect their political participation in the society of Iran.

Methodology: The researcher-made questionnaire was used by experts to determine its validity. Cronbach's alpha coefficient was used to evaluate its reliability for all variables. Regression coefficient, Mann-Whitney and KruskalWallis tests were used for data analysis and hypotheses testing. The sample size was calculated by the Cochran formula, and 383 individuals were selected by using simple random multi-stage cluster sampling.

Main Findings: The regression results indicate that the generalized social and political trust could determine $9 \%$ and $11 \%$, respectively of changes independent variable, which was the political participation of citizens in Jahrom City. The theoretical foundations of the research are based on the theories of Robert Putnam, Gabriel Mandel, Francis Fukuyama, Nicholas Luhmann, Jürgen Habermas, Martin Lipset, and Robert Dose.

Applications of this study: The present study is an applied study in terms of purpose, a practical-field study in terms of data collection, a large-scale study in terms of scale, and a short-term cross-sectional study in terms of time. The statistical population of this research comprises the holders of voting rights, those aged 18 years or more living in Jahrom city.

Novelty/Originality of this study: The contextual factors such as gender, marital status, income, job, and social class did not show a significant relationship with political participation, which may be due to the homogeneity of political behavior in cities due to the lack of individual characteristics and, consequently, the weakness of individualism in smaller social settings.
\end{abstract}

Keywords: Political Participation, Social Trust, Political Trust, Citizens, Jahrom City.

\section{INTRODUCTION}

The experience of developed and industrialized countries during the past century has proved the considerable effect of political participation on the national development of such countries. It is essential to study the political participation in all human communities as such a study not only figures out the social and political demands of people but also recognizes and directs the political behavior of citizens. Participation can be done in various forms and types but political participation is the most significant and effective type of participation at the national level with different definitions. However, many believe that participation in every society depends on the citizens so that if people do not have citizenship rights in their societies, there will be limited participation, in particular political participation (Rasekh, 2018). Among different kinds of political participation, direct and indirect participation are more strategic and practical ones. Indirect participation is seen in most democratic societies except for the Swiss and some of the small societies in different parts of the world. In indirect participation, people select some members as their agents in order to engage in the decision-making process (Rash, 2012, 123). It is vital for ruling powers to participate in the political process as the legitimacy of systems depends on the participation of people in existing political systems without consideration of their names. Hence, political participation in the world is the origin of a legitimate political power so this is an important issue for regimes (Sheikh Noori et al. 2009).

The first step in the examination of political participation is a reliable definition of this issue that is a challenging process as there are various definitions and interpretations. Various definitions of participation indicate people's engagement in their social and political fate (Huntington, 2002, 77).

Political participation in all of the societies is affected by different factors such as demographic features including age, gender, education, income level, living place, and class affiliation. In addition to demographic factors, political and social trusts are also factors affecting political participation (Seligman, 1997). Political trust is defined as the general trust existing in the policy people's evaluation of the tasks done by the government in comparison with their expectations from the government's efficiency. There is a kind of transactional relationship between citizens and the ruling political system in the conceptual nature of political trust. People need to make a relationship with the government in order to meet their demands such as security, comfort, and participation in social affairs. Such need is increasing due to developing societies and rising division of labor and expanding abstract systems; accordingly, it is not possible to 
separate from the political system (Giddens, 2008, 109). In societies with high social and political trust, there is a higher rate of responsibility in low levels of the society; while there is more scape from the responsibility in societies with lower trust leading to less political participation (Abaee, 2016, 180). Political trust reflects the high level of trust in the society; therefore, the political trust is one of the aspects of social trust that is an essential factor for a dynamic political system but the social trust is defined as doubting future social actions of others (Sedighi et al. 2011, 173). The confidence between citizens and people would reduce the hazards and risks of participation in public and political affairs also improve the social institutions and civil society in favor of sound, stable and efficient democracy.

Importance of three categories of political participation, social trust and political trust led to motivation for research in the form of Ph.D. dissertation in Jahrom City, because the recent elections showed that patterns of people's political behavior in small towns affect the election process and appointment of officials in a political system so that it has been a national case. Jahrom is one of the old cities in Iran that its citizens have been always playing role in the political system of Iran; they have had active participation in different elections, in particular after the Islamic Revolution of Iran. Like other cities of Iran, the substantial issue of political participation in this city is confined to different elections so that there are fewer other participative activities such as membership in political parties, groups, and associations. If the participation of local elites in political institutions is one of the measures of participation, Jahrom City has been successful in this case compared to the other cities. Therefore, Jahrom City is a proper case study for political participation in an average city by consideration of different research aspects.

In previous research, underlying factors such as gender, marital status, income, occupation, and social class have not shown a significant relationship with political participation, but given that this may be due to homogeneous political behavior in cities due to lack of individual characteristics and consequently, the weakness of individualism in social environments is smaller. In this study, we try to address this issue by examining this possible obstacle and conducting a more specific study.

\section{LITERATURE REVIEW}

The research background is shown in a table in order to see the results briefly and perfectly.

Table 1: Review of previous studies

\begin{tabular}{lll}
\hline Researcher & Title & Results \\
\hline$\underline{\underline{(2017)}}$ & $\begin{array}{l}\text { The role of social capital in } \\
\text { political participation of Iran }\end{array}$ & $\begin{array}{l}\text { Social capital contributes to participative } \\
\text { relationships between individuals and institutions } \\
\text { leading to participation in all of the different fields } \\
\text { particularly in political one; such result is obtained } \\
\text { due to the effect of social capital on the planning and } \\
\text { enrichment of social, political and organizational } \\
\text { culture by encouraging and improving social } \\
\text { occupational and professional institutions. }\end{array}$ \\
\hline
\end{tabular}

Rahimzadeh (2016) The role of social capital in According to Putnam Theory, three major indicators political participation of social capital indicate the connection between social capital and political participation; these factors include social trust, social norms, and social networks. Research findings show that social capital not only modifies but also promotes coherence, solidarity and confidence in the society leading to political participation of individuals and mutual relationships between people and government.

\begin{tabular}{|c|c|}
\hline $\begin{array}{l}\text { Abdollahian\& } \\
\text { Kermani }(2015)\end{array}$ & $\begin{array}{l}\text { Explaining the relationship } \\
\text { between social capital of } \\
\text { Iranian users in the social } \\
\text { network of Facebook and their } \\
\text { political participation in the real } \\
\text { world }\end{array}$ \\
\hline
\end{tabular}

The obtained results indicated that an increase in the social capital of Facebook users led to a rise in their political participation in the real world. Moreover, among indicators of social capital, openness or limit of friends' network, open or limited networks of groups and pages, network congestion and accessibility to resources are four factors that determine the political participation of users.

\begin{tabular}{lll}
\hline$\underline{\text { Panahi }}$ Banifatemeh (2016) & $\begin{array}{l}\text { Political culture and political } \\
\text { participation of women }\end{array}$ & $\begin{array}{l}\text { The political culture of women affects their political } \\
\text { participation. In addition, there is a positive and } \\
\text { significant relationship between political } \\
\text { participation of women and all of the cultural- } \\
\text { political components including attitude toward the } \\
\text { political system, ruling political elites, political } \\
\text { knowledge (mobilization), women's attitude toward }\end{array}$ \\
&
\end{tabular}


their political power and considering it as a normal right.

$\begin{array}{ll}\text { Nazari et al. (2014) } & \begin{array}{l}\text { Study of the relationship } \\ \text { between } \\ \text { political participation of women }\end{array} \\ \text { sociability and }\end{array}$

Nikpour Ghanavati et al. (2012)
Study of the socioeconomic factors associated with political participation among women older than 18 in Borazjan

$\begin{array}{ll}\text { Jafarinia (2011) } & \begin{array}{l}\text { Socioeconomic factors } \\ \text { affecting political participation } \\ \text { among citizens of Khormoj }\end{array}\end{array}$

This study examines the effect of sociability on the political participation of women at high levels of decision-making in Iran after the revolution using the descriptive-analytical approach. The obtained results show that women consider the policy as the men's field and are not interested in political participation, particularly in the power scene because they have different levels of sociability and gender stereotypes imposed on them by some institutions such as families, media, schools, and educational institutes.

Findings indicate that there is a significant relationship between political participation of women and birthplace, education level, job, social class, religion, income level, use of mass media, the political behavior of the family and friends, and interest in political programs. Nevertheless, there is not any significant relationship between political participation and age, marital status and ethnicity. According to the results obtained from multivariate regression analysis, 5 variables of religious orientation, the political behavior of friends, interest in political programs, use of mass media and education level could explain $47 \%$ of variances independent variable.

The findings of this study demonstrated that men were more interested in political participation compared with women and such participation increased in line with the rise in education level. There was a higher desire in high social classes to participate in the political process compared with lower classes. There was not any relationship between political participation and age, living place, and marital status. Among research variables, education level and organizational relationships with beta coefficients of 0.47 and 0.28 , respectively, had the highest effect on political participation. $52.5 \%$ of the variance in political participation was explained by using the variance of a linear combination of independent variables.

Ghafari et al. (2010) The role of factors affecting the political participation among students of political and technical sciences at Tehran University

According to the research findings, political sciences students are more influenced by their major within political participation in comparison with technical students. On the other hand, technical students are more affected by the political atmosphere of their college compared to students of political sciences. There was not any significant relationship between education place and political participation.

Nygard et al. (2015) Does Social Capital Enhance Political Participation of Older Adults living in Finland and Sweden?

Research results show that those individuals who are voluntary members of the social networks and organizations and trust in them are more interested in political participation; however, there is a different logic behind their participation.

\begin{tabular}{ll}
\hline Hays (2014) & $\begin{array}{l}\text { Study of the relationship There is a fundamental political organization in } \\
\text { between informal networks and USA, which works in favor of the poor and workers; } \\
\text { trust in neighborhoods and hence, associations and organizations can protect the } \\
\text { political participation of interest of people who live in a specific } \\
\text { residents }\end{array}$ \\
\hline
\end{tabular}
Hoffman \& Dowd The relationship between People who have religious orientation are cognitive 


\begin{tabular}{|c|c|c|}
\hline$\underline{(2014)}$ & $\begin{array}{l}\text { religious attitude (Islam and } \\
\text { Christianity) and political } \\
\text { participation in Nigeria, } \\
\text { Uganda, and Senegal }\end{array}$ & $\begin{array}{l}\text { so that religion highly affects their political actions. } \\
\text { In addition, findings show that two Islam and } \\
\text { Christianity religions ask people to participate in } \\
\text { social affairs, but there is a higher participation rate } \\
\text { in Muslims compared to Christians. }\end{array}$ \\
\hline Teorell (2013) & $\begin{array}{l}\text { Linking Social Capital to } \\
\text { Political } \\
\text { Voluntary Associations and } \\
\text { Networks of Recruitment in } \\
\text { Sweden }\end{array}$ & $\begin{array}{l}\text { Participation in organizations either voluntary or } \\
\text { compulsory leads to the political participation of } \\
\text { individuals. }\end{array}$ \\
\hline
\end{tabular}

Comparison between previous studies and present paper indicates that this study is innovative in terms of statistical population and study of the relationship between some factors including generalized social trust, generalized political trust, and political participation (Gross, K., Aday, S., \& Brewer, P. R. (2004), Lipset \& Dose. 1994, 379-418, SchmittBeck, R., \& Wolsing, A. (2010)).

According to Robert Putnam, the higher the level of trust in a society, the higher the participation level will be possible. Trust depends on the anticipation of behavior. When a person (or institute) promises you to do something, you cannot trust him/her; you trust such person based on your familiarity with mood, behavior, possible choices, and abilities of that person and then you guess that he/she can fulfill the promise (Putnam, 2001, 292) and (Barkan, 1998, 64). Francis Fukuyama has a kind of economic approach to the trust by focusing on the protection of social capital as a certain set of norms and informal values that are common among members of a group who have cooperation. Participation in values and norms does not create social capital by itself, because such values may be negative. He knows the economy as the most important element of human society and believes that there is a direct connection between the economy and culture of a society. Welfare and the ability of a nation to compete with other societies depend on an extensive cultural trait called "trust" that exists in society (Darani \& Shirani, 2008, 8). Nicholas Luhmann believes that the law and legitimate actions reduce the inherent risk of trust by improving collaborations not by punishing lawbreakers or settling disputes and conflicts.

Table 2: Theories used to deign research hypotheses

\begin{tabular}{|c|c|c|c|c|}
\hline Hypothesis & Theorist & $\begin{array}{l}\text { Independent } \\
\text { variable }\end{array}$ & $\begin{array}{l}\text { Dependent } \\
\text { variable }\end{array}$ & Reference \\
\hline $\begin{array}{l}\text { The relationship between political } \\
\text { trust and political participation }\end{array}$ & Robert Putnam & Political trust & $\begin{array}{l}\text { Political } \\
\text { participation }\end{array}$ & Putnam (2001) \\
\hline $\begin{array}{l}\text { The relationship between social } \\
\text { trust and political participation }\end{array}$ & Gabriel Almond & Social trust & $\begin{array}{l}\text { Political } \\
\text { participation }\end{array}$ & $\frac{\text { Rash (2012); }}{(1998)}$ Barkan \\
\hline $\begin{array}{l}\text { The relationship between social } \\
\text { trust and political participation }\end{array}$ & $\begin{array}{l}\text { Francis } \\
\text { Fukuyama }\end{array}$ & Social trust & $\begin{array}{l}\text { Political } \\
\text { participation }\end{array}$ & Darani, Rashidi (2008) \\
\hline $\begin{array}{l}\text { The relationship between } \\
\text { demographic variables and } \\
\text { political participation }\end{array}$ & Lipset \& Dose & $\begin{array}{l}\text { Demographic } \\
\text { variables }\end{array}$ & $\begin{array}{l}\text { Political } \\
\text { participation }\end{array}$ & Lipset, Dose (1994) \\
\hline
\end{tabular}

Following hypotheses have been presented based on the research objectives:

Main Hypothesis: There is a significant relationship between political and social trust, demographic factors, and political participation of citizens with coting right in Jahrom City. (Ashrafi, E., Montazeri, A., Mousavi, M., VaezMahdavi, M. R., \& Asadi-Lari, M. 2012).

\section{METHOD}

This is a field study with a survey method in terms of methodology, applied research in terms of objective, an extensive study in terms of extent, a micro-study in terms of domain and cross-sectional research in terms of time. The statistical population of this research comprises all of the individuals older than 18 who live in Jahrom city and have voting right; the number of people with the aforementioned features is about $70000(\mathrm{~N}=70000)$ in accordance with the 2016 census. The research sample was calculated to 383 members $(n=383)$ using Cochrane formula within a simple random sampling method in which, Jahrom was divided into five regions of north, south, east and west then some streets and squares of each area were selected randomly. This study includes the microanalysis level due to evaluating citizens' attitudes toward considered variables and factors. Analysis unit in this research includes citizens older than 18 in Jahrom City and the observation unit is individual as the researcher-made 73-item questionnaire was filled out based on the 5-Likert scale by individuals.

At the next step, research methodology including the definition of a statistical population, sample size, analysis unit, the definition of dependent and independent variables, data collecting method, sampling method, extraction method, and data analysis at two descriptive and inferential statistics was implemented through SPSS Software. Research findings have been summarized herein. 
Table 3: Situation of research variables

\begin{tabular}{|c|c|c|c|}
\hline Variable & Item & Scoring & Validity \\
\hline Political participation & $1-12$ & $5=$ very high, high, average, low, and very low $=1$ & 0.815 \\
\hline \multirow[t]{2}{*}{$\begin{array}{l}\text { Generalized social- } \\
\text { political trust }\end{array}$} & $13-20$ & $\begin{array}{l}\text { 5=strongly agree, agree, somewhat, disagree, strongly } \\
\text { disagree }=1\end{array}$ & \multirow[t]{2}{*}{0.720} \\
\hline & $21-29$ & $5=$ very high, high, average, low, never=1 & \\
\hline Contextual factors & $67-73$ & - & - \\
\hline
\end{tabular}

Items 35 and 55 are scored reversely.

Table 4: Conceptual and operational definitions of variables

\begin{tabular}{|c|c|c|c|c|}
\hline \multirow[t]{2}{*}{ Variable } & \multirow[t]{2}{*}{ Status } & \multirow[t]{2}{*}{ Conceptual definition } & \multicolumn{2}{|c|}{ Operational definition } \\
\hline & & & Indicator & Item \\
\hline \multirow{3}{*}{ 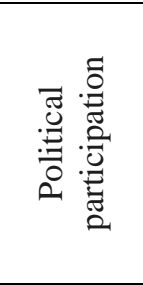 } & \multirow{3}{*}{$\begin{array}{l}\overrightarrow{0} \\
\frac{0}{0} \\
\overline{0} \\
\stackrel{0}{0}\end{array}$} & \multirow{3}{*}{$\begin{array}{l}\text { Huntington defines political participation as a set of } \\
\text { activities done by citizens to influence over the } \\
\text { regime and support the political system. According } \\
\text { to this definition, people can participate in political } \\
\text { affairs by imposing pressure, competing and } \\
\text { influencing over the regime on one hand and support } \\
\text { the system on the other hand (Huntington, 2002, 15) }\end{array}$} & Electoral actions & $1-3$ \\
\hline & & & $\begin{array}{c}\text { Participation in } \\
\text { political associations } \\
\text { and institutes }\end{array}$ & $4-7$ \\
\hline & & & $\begin{array}{l}\text { Political opinions and } \\
\text { comments }\end{array}$ & $8-12$ \\
\hline \multirow{5}{*}{ 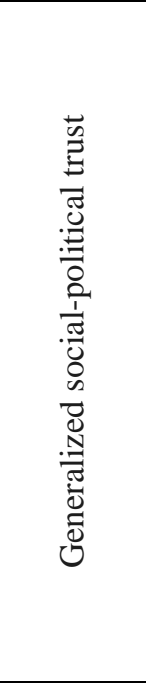 } & \multirow{5}{*}{ 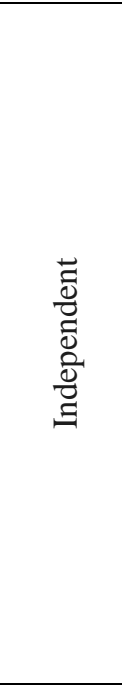 } & \multirow{5}{*}{$\begin{array}{l}\text { Social trust is a concept appeared in the process of } \\
\text { social relationships between individuals and } \\
\text { organizations of the community. Anthony Giddens } \\
\text { defines trust as a confidence in or reliance on the } \\
\text { nature or trait of a person or accuracy of sayings. In } \\
\text { the opinion of Putnam, trust improves voluntary and } \\
\text { mutual associations that in turn lead to a higher level } \\
\text { of trust. } \\
\text { Political trust is defined as the general understanding } \\
\text { ruling the politics and peoples' judgment about the } \\
\text { governments and tasks done by it for their } \\
\text { expectations from the government efficiency. There } \\
\text { is a transactional relationship between citizens and } \\
\text { the political system, which is hidden in the concept } \\
\text { of political trust. The political trust of citizens } \\
\text { depends on the behavior of the government and its } \\
\text { officials and institutes (Yousefvand et al. 2006, 85). }\end{array}$} & $\begin{array}{c}\text { Generalized social } \\
\text { trust }\end{array}$ & $13-15$ \\
\hline & & & $\begin{array}{c}\text { Trust in the political } \\
\text { system }\end{array}$ & $16-20$ \\
\hline & & & $\begin{array}{c}\text { Trust in officials, } \\
\text { politicians and } \\
\text { political actors }\end{array}$ & $21-29$ \\
\hline & & & $\begin{array}{c}\text { Trust in political } \\
\text { institutions }\end{array}$ & $21-29$ \\
\hline & & & Faithfulness & $37-49$ \\
\hline \multirow{7}{*}{ 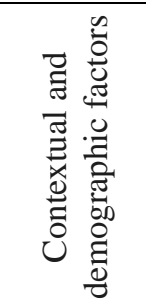 } & \multirow{7}{*}{$\begin{array}{l}\overrightarrow{0} \\
\frac{0}{0} \\
\bar{D} \\
\frac{0}{0} \\
\text { E }\end{array}$} & & Age & 67 \\
\hline & & & Sex & 68 \\
\hline & & & Marital status & 69 \\
\hline & & - & Income level & 70 \\
\hline & & & Job & 71 \\
\hline & & & Education level & 72 \\
\hline & & & Social class & 73 \\
\hline
\end{tabular}

\section{RESULTS AND DISCUSSION}

To analyze hypotheses 1-3, Spearman correlation coefficient test, determination coefficient test, F test, and regression coefficient test were used. To analyze hypothesis 4, Spearman correlation coefficient, F, Mann-Withney, and KruskalWallis tests were used.

Result of hypothesis 1: according to the significance level, the obtained results indicated that Spearman correlation coefficient between generalized social trust and political participation equals 0.312 ; generalized social trust could explain $9 \%$ of variances in political participation $\left(\mathrm{R}^{2}=0.099\right)$. There was a linear relationship between independent variables and the dependent variable (ANOVA=41.972). According to the regression equation, as the regression coefficient is larger, variances in the independent variable have an ideal effect on the dependent variable. Beta obtained to 0.315 and $t$ value equaled 6.479. Positive $t$ value indicates the direct connection between these two variables. It means that there is a significant relationship between political participation and generalized social trust. Generally, this hypothesis is confirmed. 
Table 5: Examining hypotheses 1-4

\begin{tabular}{|c|c|c|c|c|c|c|c|c|c|}
\hline 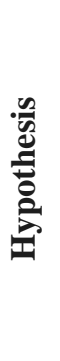 & 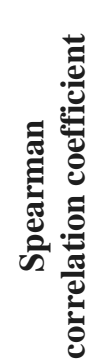 & 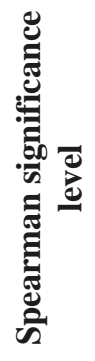 & 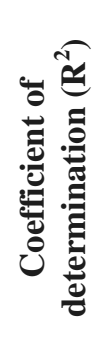 & 工 & 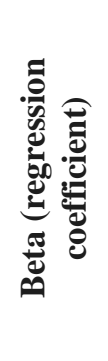 & 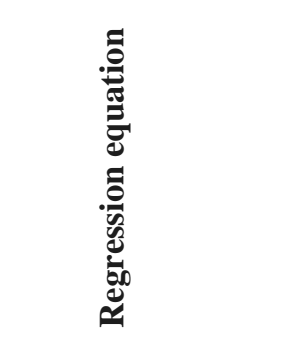 & - & $\ddot{\dot{00}}$ & 氖 \\
\hline 1 & 0.312 & 0.000 & 0.099 & 41.972 & 0.315 & $Y=1.105 x+24.388$ & 6.479 & 0.000 & Confirmed \\
\hline 2 & 0.325 & 0.000 & 0.110 & 46.971 & 0.331 & $Y=0.695 x+24.864$ & & 0.000 & Confirmed \\
\hline 3 & 0.361 & 0.000 & 0.127 & 54.728 & 0.356 & $Y=0.439 x+24.603$ & 7.398 & 0.000 & Confirmed \\
\hline
\end{tabular}

Result of hypothesis 2: according to the significance level, the obtained results indicated that Spearman correlation coefficient between generalized political trust and political participation equals 0.325 ; generalized political trust could explain $11 \%$ of variances in political participation $\left(\mathrm{R}^{2}=0.110\right)$. There was a linear relation between independent variables and the dependent variable (ANOVA=46.971). According to the regression equation, as the regression coefficient is larger, variances in the independent variable have an ideal effect on the dependent variable. Beta obtained to 0.331 and $t$ value equaled 6.854. Positive $t$ value indicates the direct connection between these two variables. It means that there is a significant relationship between political participation and generalized social trust. Generally, this hypothesis is confirmed.

Result of hypothesis 3: according to the significance level, the obtained results indicated that Spearman correlation coefficient between trust in officials and agents of the system and political participation equals 0.361 ; this variable could explain $12 \%$ of variances in political participation $\left(\mathrm{R}^{2}=0.127\right)$. There was a linear relation between independent variables and the dependent variable (ANOVA=54.728). According to the regression equation, as the regression coefficient is larger, variances in the independent variable have an ideal effect on the dependent variable. Beta obtained to 0.356 and $t$ value equaled 7.398. Positive $t$ value indicates the direct connection between these two variables. It means that there is a significant relationship between political participation and trust in officials and agents of the system. Generally, this hypothesis is confirmed.

Result of hypothesis 4: The relationship between political participation and demographic factors

Table 6: Examining hypotheses 4

\begin{tabular}{|c|c|c|c|c|}
\hline Contextual factors & Mean & Frequency & P-value & \\
\hline \multirow{5}{*}{ Age } & 18-30 years old & 197.06 & 159 & \multirow{5}{*}{$\begin{array}{l}\mathrm{P}=0.033 \\
\text { Chi-Square }=8.710\end{array}$} \\
\hline & $31-43$ & 193.19 & 154 & \\
\hline & $44-56$ & 149.83 & 53 & \\
\hline & $57-67$ & 217.29 & 12 & \\
\hline & Invalid response & - & 5 & \\
\hline \multirow{3}{*}{ Sex } & Male & 190.08 & 198 & \multirow{3}{*}{$\begin{array}{l}\mathrm{P}=0.794 \\
\text { Mann-Withney=17934 }\end{array}$} \\
\hline & Female & 193.03 & 184 & \\
\hline & Invalid response & - & 1 & \\
\hline \multirow{3}{*}{ Marital status } & Single & 192.45 & 133 & \multirow{3}{*}{$\begin{array}{l}\mathrm{P}=0.850 \\
\text { Mann-Withney }=16298.500\end{array}$} \\
\hline & Married & 190.22 & 284 & \\
\hline & Invalid response & - & 2 & \\
\hline \multirow{4}{*}{ Income level } & $\begin{array}{l}\text { Less than } 1 \text { million } \\
\text { Rial }\end{array}$ & 33.468 & 32 & \multirow{4}{*}{$\begin{array}{l}P=0.543 \\
F=0.612\end{array}$} \\
\hline & 1-4 million & 33.130 & 199 & \\
\hline & 4 million and above & 30.857 & 28 & \\
\hline & Invalid response & - & 124 & \\
\hline \multirow{6}{*}{ Job } & Governmental & 34.187 & 32 & \multirow{5}{*}{$\begin{array}{l}P=0.612 \\
F=0.672\end{array}$} \\
\hline & Private & 33.761 & 21 & \\
\hline & Self-employed & 32.636 & 179 & \\
\hline & Unemployed & 31.166 & 90 & \\
\hline & Invalid response & - & 58 & \\
\hline & Illiterate & 35.166 & 6 & \\
\hline
\end{tabular}




\begin{tabular}{|c|c|c|c|c|}
\hline \multirow{6}{*}{ Education level } & High school & 34.637 & 69 & \multirow{6}{*}{$\begin{array}{l}\mathrm{P}=0.026 \\
\mathrm{~F}=2.586\end{array}$} \\
\hline & Diploma & 30.330 & 133 & \\
\hline & Associate degree & 32.763 & 38 & \\
\hline & $\mathrm{BA}$ & 34.837 & 74 & \\
\hline & MA and higher & 32.954 & 22 & \\
\hline & Invalid response & - & 41 & \\
\hline \multirow{4}{*}{ Social class } & High & 33.222 & 36 & \multirow{4}{*}{$\begin{array}{l}\mathrm{P}=0.475 \\
\mathrm{~F}=0.746\end{array}$} \\
\hline & Average & 33.087 & 239 & \\
\hline & Low & 31.587 & 97 & \\
\hline & Invalid response & - & 11 & \\
\hline
\end{tabular}

According to the findings obtained from the relationship between political participation and contextual factors of citizens, there was not any significant relationship between political participation and factors of sex, marital status, income level, job, and social class (P-Value>0.05).

Moreover, the highest frequency of political participation was seen in individuals in the age range of 18-30 ( $\mathrm{n}=159)$ and those who had a diploma degree $(n=133)(P-V a l u e<0.05)$.

Results of the first hypothesis were in line with studies conducted by Putnam (2000), and Rahimzadeh (2016). Rahimzadeh (2016) expressed that research findings indicate that social capital not only modifies the relationships but also improves coherence, solidarity and sense of confidence in the society leading to political participation of individuals and keeping their mutual relationships. An article concluded that the relations between variables could be shown at macro levels such as political and economic development, and inequality. Results obtained from his study show that there is a connection between political participation in institutions (voting) or non-institutions (participation in peaceful demonstrations) and social capital, which is one general indicator of trust, confidence in government and public engagement. Macro variables show the connection between social capital and political participation so that the rapid change in general values leads to the participation and activity of individuals. Moreover, the correlation between social capital and political participation depends on social contexts. In the opinion of Putnam (2000), social capital includes different aspects of social organization such as trust, norms and networks that can improve the efficiency of society by facilitating the concerted actions. Putnam believes that resources of social capital usually are self-booster and selfprocessor; the reproduction cycle of virtues contributes to social balance along with a high level of trust, mutual interaction, civil participation and collective welfare. The aforementioned features indicate a civil society. In the contrary, lack of such traits in non-civil societies is also a self-booster, because abjuration, mistrust, deception, exploitation, isolation, disorder, and stagnation intensify themselves within the oppressive atmosphere of vicious periods.

Results of the second hypothesis were matched with studies conducted by Nygard et al. (2015), Hays (2015), and Putnam (2000). Nygard et al. (2015) found that those individuals who voluntary participate and trust in social networks and organizations are more willing to participate in political affairs; however, they have different logic for their participation. In the opinion of Hays (2015), there is not a fundamental political organization in US to support the poor and workers; therefore, the establishment of the association in a specific neighborhood is a mechanism that can protect the interest of individuals. Division of neighborhoods based on the class and race is harmful to residents with the lowincome level in a place; nevertheless, geographical concentration can organize the political activities in such places. Putnam (2000) concluded that it is possible to separate civil and non-civil regions in Italy. Civil areas are those societies in which, life has been organized horizontally; citizens trust in each other and participate in public decisions. They follow the public issues in the press eagerly and obey the law. Non-civil areas have different features compared to the civil areas because the concept of citizen is strange in them. Participation in public and political affairs by individuals depends on their personal interests. People do not participate as much as required in social and cultural associations. Corruption is a norm in such societies, the law is always violating, and most of the people feel that are weak, unhappy, and exploited.

Results of the third hypothesis showed that sometimes people make a relationship with non-individual actors; in this case, another aspect of trust is shown that reveals impersonal structures. Either at interpersonal or macro levels, political trust is defined as lack of any doubt in political actions of political actors, institutes and procedures in the future. Participation allows citizens to replace the officials and change the government's structure. Hence, participation makes the officials be responsible and liable. Political participation plays a vital role in an indirect democracy. The election is the main mechanism to actualize democracy. Final power is in the hands of people and people delegate this power to their agents. In this case, participation makes it possible for citizens to change officials and government so the official should be responsible for the nation's demands.

Results of the fourth hypothesis were in line with studies conducted by Nikpour Ghanavati et al. (2012), Panahi and Banifatemeh (2015), Nazari et al. (2014), and Jafarinia (2011). Findings obtained by Nikpour Ghanavati et al. (2012) indicated that there is a significant relationship between political participation of women and birthplace, education level, job, social class, religious orientation, income level, use of mass media, the political behavior of family and friends, and 
interest in political programs. There was not any significant relationship between political participation and marital status and ethnicity. According to the multivariate regression analysis, 5 variables of religious orientation, the political behavior of friends, interest in political programs, use of mass media and education could explain $47 \%$ of changes independent variable. Panahi and Banifatemeh (2015) concluded that the political culture of women had an effect on their political participation. Also, there was a positive and significant relationship between political participation of women and all of the cultural-political components including attitude toward the political system, the ruling political elites, political knowledge, women's attitude toward their political power, and considering the political participation of women as a norm in society. Nazari et al. (2014) showed that there is a low rate of political participation of women in the structure of the Islamic Republic of Iran. Women consider the policy as the men's field and are not interested in political participation, particularly in the power scene because they have different levels of sociability and gender stereotypes imposed on them by some institutions such as families, media, schools, and educational institutes. Jafarinia (2011) demonstrated that men were more interested in political participation compared with women and such participation increased in line with the rise in education level. There was a higher desire in high social classes to participate in the political process compared with lower classes. There was not any relationship between political participation and age, living place, and marital status. Among research variables, education level and organizational relationships with beta coefficients of 0.47 and 0.28 , respectively, had the highest effect on political participation. 52.5\% of the variance in political participation was explained by using the variance of a linear combination of independent variables. In addition, the political participation of young people was lower than the political participation of elderlies. Lipset believes that there is a close relationship between political participation and socioeconomic factors; the positive relationship between political participation and socioeconomic classes has been proved in many of the studies conducted by Lipset. However, there are numerous evidences indicating that political participation may differ based on the socioeconomic situation, gender, age, personality, and the political field of participation. According to the first hypothesis that examines the relationship between generalized social trust and political participation, it is recommended that political officials of the country remove the people's doubt in social-political actions by doing decisive, practical, suitable and timely social-political actions. The social collaboration of people should be supported. The functional system of the country should be democratic and collective behaviors should be facilitated and encouraged for the sake of public interests. According to the second hypothesis that examines the relationship between generalized political trust and political participation, it is suggested to prepare the field for participation and cooperation of people in the political decisions of the society. The conditions should be prepared for political activities in local associations, political parties, national organizations, and political meetings with officials. People should be allowed to express their political opinions freely and easily and present their critics and suggestions. According to the third hypothesis that examines the relationship between political participation and trust in the system's officials and actors, it is recommended that tasks of the government, and system's officials and actors be executed under the supervision and suitable rules in order to meet people's expectations. Efficiencies of the government and political positions should be increased based on the practical and proper planning then these programs should be informed. Such specific demands of people such as security, comfort, and participation in society affairs should be satisfied in order to make a connection between people and officials. Political officials also should fulfill their electoral promises and programs. According to the fourth hypothesis that examines the relationship between political participation and contextual factors.

\section{CONCLUSION}

This part of the study presents the empirical and theoretical results obtained from the research questions. This study was conducted to examine the sociological factors affecting political participation by focusing on political and social trust among citizens older than 18 (citizens who have voting right) in Jahrom City. After clarifying the research subject, studies conducted in Iran and foreign studies were reviewed; then different theories about sociological factors affecting political participation were studied by focusing on social and political trust.

The obtained results showed that the highest frequency of studied unit was seen in the age range of 18-30 (n=159) $(42.1 \%)$ and the lowest frequency was seen in the age range of 57-67 $(n=12)(3.1 \%)$. The highest frequency of the studied unit was seen in men $(n=198)(51.7 \%)$ and married persons $(n=248)(64.8 \%)$. The highest frequency of income was seen in people with an income level of 1-4 million $(\mathrm{n}=199)(52 \%)$ and the lowest frequency was seen in people with an income level of 5million-1billion $(\mathrm{n}=28)(7.3 \%)$. The highest frequency of jobs was seen in self-employed persons $(\mathrm{n}=179,46.7 \%)$ and the lowest frequency was seen in private jobs $(\mathrm{n}=21,5.5 \%)$. In addition, the highest frequency in education level was related diploma $(n=133,34.7 \%)$ and the lowest frequency was related to illiterate people $(n=6$, $1.6 \%)$. The highest frequency of responsiveness was seen in individuals with average social class $(\mathrm{n}-239,62.4 \%)$ and the lowest frequency was seen in people with high social class $(n=36,9.4 \%)$. The highest mean was related to religiosity with a value of $40.362 \pm 7.74$ and the lowest mean was related to the variable of use of national media with a value of $3.956 \pm 1.19$.

\section{LIMITATION AND STUDY FORWARD}

It is possible to increase the number of selected individuals in relation to what is considered in this study in order to increase the accuracy of the results. 


\section{RECOMMENDATIONS}

It is recommended to hold suitable social-political programs in mass media, schools, and workplaces for different age ranges based on their understanding. There should not be any orientation in activity or inactivity of a specific gender so individuals should be allowed to participate in political activities without considering their sex or marital status. Education level and political knowledge of people should be improved. The conditions should be prepared in order to create jobs and increase income levels so that political elites can present their creative ideas without any economic concern. Officials should do proper actions and plan great programs in order to improve the social class of people.

\section{REFERENCES}

1. Panahi, M. H., Banifatemeh, S. (2015). Political culture and women's political participation, Journal of Social Sciences, Vol. 68, Issue 68.

2. Putnam, R. (2001). Democracy and civil traditions, Translated by Mohammad Taghi Delfroz, Tehran, Salam Press Publication.

3. Jafarinia, G. (2012). Investigation of socio-economic factors affecting the political participation of citizens of Khormoj. Journal of Political Science, 7(2), 122-87.

4. Darani, K., Rashidi, Z. (2008). Investigating the definitions of concepts and how to create social capital (with emphasis on social trust), Journal of Cultural Engineering, Third Year, Pp. 43-50.

5. Rasekh, K. (2018). Reflective traditionalism, Foundations of Iranian political sociology, Tehran, Agah Pub.

6. Rash, M. (2012). Society and politics, introduction to political sociology, translated by Manouchehr Sabouri, Tehran, Aram Pub.

7. Rahimzadeh Ghazani, F. (2016). The role of social capital in political participation, First International Comprehensive Congress of Iranian Political Science, Datis Graph Development Institute.

8. Khavari, S. A., Arasteh, H., \& Jafari, P. (2016). Assessing the Level Organizational Universities Agility; Case Study of Islamic Azad University in Mazandaran. Mediterranean Journal of Social Sciences, 7(3 S2), 112.

9. Sheikh Mohammadi, A. (2017). Investigating the role of social capital in political participation in Iran, Second International Conference on New Horizons in Humanities and Management, Tehran, New Horizons of Science and Technology Association.

10. Sheikh Noori, M. A., Alizadeh Birjandi, Z. (2009). The crisis of legitimacy of the Nasserian government and its impact on Nasser al-Din Shah's attitude to modernist reforms, Islamic and Iranian History (Humanities), 19 (1 (75)), Pp. 49- 76.

11. Sedighi, B., Malek Mina, L., Ojaghi Ozbari, M. (2011). Study of the impact of social trust on political participation (MA Students of Roudehen Azad University, Journal of Social Research, Issue 11, summer.

12. Abaee, M. (2016). The role of political parties in institutionalizing political participation in society to gain power, Tehran: Ninth Congress of Pioneers of Progress.

13. Abdollahian, H., Kermani, H. (2015).Explaining the relationship of Iranian users of Facebook with political participation in real world, Social Studies and Research in Iran, Vol. IV, winter 2015, Issue 4 (16 consecutive).

14. Ghafari Hashjin, Z., Beiginia, A., Tasmim Ghatee, A. (2010). Factors affecting political participation of students of political and technical sciences of Tehran University, Political Science, Vol. 6, Issue 2, Successive 12 .

15. Conge, P. J. (1988). The concept of political participation: Toward a definition. https://doi.org/10.2307/421669

16. Giddens, A. (2013). Modernity and Individuality: Society and Personal Identity in a New Age.

17. Dose, R., \& Lipset, S. M. (1994). Political Sociology, Translation: Mohammad Hossein Farjad.

18. Nazari, M., Ali Hosseini, A., Imam Jomezadeh, S. J., Pour Ranjbar, M. (2016). Investigating the relationship between sociability and political participation of women, Journal of Women: spring and summer, Vol. 5, Issue 1, Pp. 161-185.

19. Nikpour Ghanavati, L., Moini, M., Ahmadi, H. (2012). Investigation of socio-economic factors related to political participation, Sociology of Women (Woman and Society), Issue 3, spring. Pp. 39-61.

20. Huntington, S. (2002). The third wave of democracy at the end of the twentieth century, translated by Ahmad Shohsa. Tehran, Daily Pub.

21. Barkan, S. E. (1998). Race, issue engagement, and political participation: Evidence from the 1987 general social survey. Race and Society, 1(1), 63-76. https://doi.org/10.1016/S1090-9524(99)80186-7

22. Hays, R. A. (2015). Neighborhood networks, social capital, and political participation: The relationships revisited. Journal of Urban Affairs, 37(2), 122-143. https://doi.org/10.1111/juaf.12137

23. Hoffman, A. and Dowd, R. (2014). Religion Gender and Political Participation in Africa Lessons from Nigeria Senegal and Uganda De: Lessons from Nigeria, Senegal and Uganda, Department of Political Science, University of Notre Dame.

24. Nygård, M., Nyqvist, F., Steenbeek, W., \& Jakobsson, G. (2015). Does social capital enhance political participation of older adults? A multi-level analysis of older Finns and Swedes. Journal of International and Comparative Social Policy, 31(3), 234-254. https://doi.org/10.1080/21699763.2015.1069207

25. Seligman, A. B. (2000). The problem of trust. Princeton University Press. 
26. Teorell, J. (2003). Linking social capital to political Participation: Voluntary associations and networks of recruitment in Sweden 1. Scandinavian Political Studies, 26(1), 49-66. https://doi.org/10.1111/14679477.00079

27. Gross, K., Aday, S., \& Brewer, P. R. (2004). A panel study of media effects on political and social trust after September 11, 2001. Harvard International Journal of Press/Politics,9(4), 49-73. https://doi.org/10.1177/1081180X04269138

28. Schmitt-Beck, R., \& Wolsing, A. (2010). European TV environments and citizens' social trust: Evidence from multilevel analyses. Communications, 35(4), 461-483. https://doi.org/10.1515/comm.2010.024

29. Ashrafi, E., Montazeri, A., Mousavi, M., Vaez-Mahdavi, M. R., \& Asadi-Lari, M. (2012). Influence of sociodemographic features and general health on social capital: Findings from a large population-based survey in Tehran, Iran (Urban-HEART). Public health, 126(9), 796-803. https://doi.org/10.1016/j.puhe.2012.06.013

30. Moy, P., \& Scheufele, D. A. (2000). Media effects on political and social trust. Journalism \& Mass Communication Quarterly, 77(4), 744-759. https://doi.org/10.1177/107769900007700403 